\title{
A Study of Negotiating Strategies in South Korea
}

\author{
Wang Hui-ya (Anny) \\ Minghsin University of Science and Technology, Hsinchu city, Taiwan
}

\begin{abstract}
Under the globalization of rapid industrialization, economic growth and expansion to the global market, South Korea is attracting more and more international businesses who wish to do business with South Korean companies. It is suggested that a negotiator of an international company should understand the cultural background and the negotiating strategies first. This study aims to investigate the twelve negotiating variables of negotiating with South Korean companies. It is hoped that European, Asian, and American companies who wish to do business with South Korea can benefit from the results of research. This study results will be provided as reference of enterprises, schools and students.
\end{abstract}

Keywords: international business, negotiating strategies

\section{Introduction}

The democratization and globalization that transformed South Korea from the destruction of the Korean War to a wealthy and developed country with prominent multinational conglomerates such as Samsung, LG, and Hyundai-Kia. The Miracle on the Han River is a term used to refer to South Korea's economic growth, including rapid industrialization, technological achievement, education boom, high living standards, modernization, etc. With the efforts to expand to the global market, South Korea host the 1988 Summer Olympics and co-host the 2002 FIFA World Cup. In less than four decades, Seoul was transformed into a global city, a center of business and commerce in Northeast Asia and a highly developed economic hub. This rapid growth will entice the people worldwide to do business with South Korea. This paper will examine the twelve negotiating variables of unique Korean cultures in order to benefit those who wish to do business in South Korea.

\section{Historical Perspective}

Korean culture has been profoundly influenced by the Confucianism for the past 5,000 years. Kung Fu-Tzu, known in Western countries as Confucius, lived in China around 500 BC. He was a teacher who offered his students a system of order during a period when China was disrupted by warfare. He had five moral disciplines to govern the five human relationships: (1) Justice and righteousness should mark the relations between sovereign and subject; (2) There should be proper rapport between father and son; (3) Separation of function between husband and wife; (4) The younger should give precedence to the elder; and (5) Faith and trust should reign over relationships between friends. In short, the five disciplines indicate the five relationships of ruler and subject, parents and children, husband and wife, brothers and sisters, and friend and friend. Confucianism stresses duty, loyalty, honor, filial piety, respect for age and seniority, and sincerity.

Wang Hui-ya (Anny), M.A. in TESOL and Early Childhood Education, Lecturer, Language Teaching Center, Minghsin University of Science and Technology. 
Koreans are friendly with their friends and treat them with the utmost respect and kindness. If someone does not have some relationship to a Korean, no loyalty or respect is due. Note that Korea has been known for most of its history as the "Hermit Kingdom”, successfully repelling "barbarian" attacks and influences until this century. Thus, foreigners and outsiders have traditionally been "non-persons", and socially indefinable; after centuries of Confucian tradition, foreigners do not exactly fall into any specific category of interpersonal relations. However, once a foreigner becomes a business associate, a fellow club member, or a colleague, he or she will be treated in the manner appropriate to one's position.

In the past, Confucian philosophy was a major influence on the role of Korean women, traditionally limiting them to the management of the large, extended family. Until this traditional perception of women is changed, sending women to open Korean business relations would be a fruitless exercise. Nowadays, many Korean women have been successful in running their own businesses.

\section{Basic Concept of Negotiation Process}

In South Korea, people are trying to maintain the environment of stable Kibun, mood or feeling of a comfortable and peaceful state of mind, both in personal life and business world. Sometimes, they avoid saying "no" or bad news, to prevent hurting others' Kibun. Knowing this culture is very important to maintain the harmony, and especially in the business world.

Nunchi is the ability to determine another person's Kibun by using the eye. As mentioned above, people need to learn from others' non-verbal and body languages, as well as the tones to get the real meaning of what they said. If you are a boss of Koreans telling them that they are doing a certain thing wrong in their work, and they may take this to mean that you are not satisfied with all their work. Another example could be: A Korean man say to you that “Are you hungry?” He is actually saying "I am hungry, can we eat now?” So if you answer "No", it would hurt his Kibun. The correct answer would be to ask the Korean what he wants to eat.

Another key principle of South Korean business culture is Inhwa, which is defined as harmony. As a collectivist society, consensus is an important element in promoting and maintaining harmony in South Korea. In the business world, this term requires that subordinates be loyal to their superiors and that superiors be concerned with the well-being of subordinates.

In South Korea, the personal relationships are essential for negotiation process. In order to be successful, it is vital to negotiate based on mutual trust and benefit.

Koreans are not comfortable doing business by individuals. In other words, Koreans are not willing to do business with a stranger without friends' introduction and support. By introducing and establishing the personal relationships, South Koreans would be more willing to consider the foreign company as a part of the group. It is suggested for the foreign company to maintain the relationship by continuously contacting the Korean company. Therefore, time should be allocated for this process, particularly during the first meeting, which is frequently used to simply establish rapport and build trust. Once good, solid relations have been recognized in South Korea, continuous reinforcement and maintenance is vital. Foreign companies should be patient doing business with Korean ones, and take the business as a long-term one instead of one-time deal. The better and stronger the personal relationship with the Korean company, the more successful the partnership would be.

\section{Selection of Negotiators}

Both Koreans and Americans who do international business must know cultures, negotiation styles, 
business practices, and the social customs of the counterpart. For example, South Koreans who are sensitive to power and status can feel insulted if an American company sends negotiators who do not match the status and age of the Koreans.

In order to become a Korean negotiator, one must have the characteristics, such as sincerity, good faith and honesty. On the other hand, personality characteristics appeared to play a greater role. For example, the Koreans are not only more emotional but also more individualistic than their Japanese and Chinese counterparts. Thus, individual reward from the successful completion of a negotiation may be an important consideration in the negotiator's mind. If a Korean negotiator does not see any particular benefit, either intrinsic or extrinsic, to concluding the transaction, it is unlikely that an agreement can be reached with the Koreans.

The Korean negotiating teams were usually smaller in comparison to the Japanese and Chinese counterparts. Yet, there are important similarities to the Japanese and the Chinese. One, similar to the Japanese, there is a certain degree of group participation. Individual responsibility is often limited to the extent that different views need to be discussed before consensus is reached among the team members. Two, the Koreans are as hierarchical as the Chinese. A Korean negotiating team is often led by a senior manager who is usually accompanied by an entourage of junior managers responsible for different functional areas. The Koreans are very status-conscious and become upset if the titles and positions of their counterparts are found below their own.

\section{Role of Individual Aspirations}

Korea is a very collectivist society. This is manifest in a close long-term commitment to the member "group", be that a family, extended family, or extended relationships. Loyalty in a collectivist culture is paramount, and over-rides most other societal rules and regulations. The society fosters strong relationships where everyone takes responsibility for fellow members of their group.

Koreans are gentle and kind to in-group members. However, they can be rude and ill-mannered to out-group members. If they think their counterpart is not likely to be an in-group member; South Koreans will feel free to exhibit an aggressive style of communication.

\section{Concern With Protocol}

The usual greeting between men is a bow, accompanied by a handshake. Maintaining the eye contact is appreciated.

The exchange of business cards plays a very important role in the introduction process. After receiving the card, it is suggested to nod your head to show your respect and thanks.

The first meeting is usually a start of the business-relationship building process. Very little might be discussed which relates to the actual business in hand for a while, with most time being spent exchanging pleasantries, discussing travel and other small trivia. It is suggested for American companies that they could view the first meeting as an essential first step or investment in creating a rewarding, trustable and long-term business relationship. It is recommended for American companies to keep contacts with the whole team, because one of the management styles of South Koreans is team-oriented.

When working with South Korean companies, American ones should value the decisions made by the senior managers. American companies should keep in mind that they need to avoid conflicts, especially in public, with senior managers. 
Speak slowly to emphasize and repeat your key points. The real level of comprehension of many English-speaking Korean business people may not be as good as their courtesy implies.

Sharing a dinner can be important in building friendships that will foster the necessary trust, as well as building a rapport that will greatly contribute to the overall success of your firm in Korea. Remember that to the Korean businessman, your social relationship is directly related to the conduct of business.

In South Korea, gift giving is part of doing business. It is done to secure favors and build relationships. Gift giving in South Korea is not seen as a bribery or corruption. The gifts from the givers' home country would be much appreciated and impressive, regardless of the price.

\section{Significance of Type of Issue}

As a foreign business person, if you can keep everyone's kibun high, then you will be able to achieve a very satisfactory working relationship. It is very difficult for Koreans to admit failure, and devastating for them to lose face. The directness of Westerners in dealing with incompetence, error, or dishonesty is thoroughly unpalatable to Koreans, whose self-esteem is always on the line.

\section{Complexity of Language}

South Korea is in high-context society, what is written is secondary to what is said or even what has been implied. In other words, communication between people can rely more on the silent language, such as body movement, facial expression, eye contact, and other nonverbal signals. In low-context societies like the US, communication is explicit; thus, a written agreement is valued over an implicit understanding.

Americans are often perceived by their South Korean counterparts as being very inflexible since they are unwilling to make any change to the original agreement. Americans think that a contract is a law and a final product; Koreans, however, think that a contract is a beginning.

Similar to indirectness, South Korean culture, with its tolerance for ambiguity, leads to a trust-based approach that can cause problems, especially in international negotiations. Koreans assume that both parties have mutual understanding. They do not carefully examine that document. From my interviewee, she thinks that she can make some small adjustment later on but still need to abide by the original contract.

\section{Nature of Persuasive Argument}

It is crucial to maintain harmony when dealing with South Korean customers. It is also important to avoid conflict. South Koreans are not trained in the Western style of argumentation and debate, and very easily lose their temper. They, then, will become direct and emotional negotiating with Americans while speaking in English. Both language deficiency and a lack of experience in logical argument can cause frustrations. Once a Korean negotiator's kibun is damaged, he/she is likely to withdraw from any communication with his/her counterpart.

\section{Value of Time}

One should always expect to schedule an appointment and attend the meeting on time. The wait time will cause the misunderstanding such as not being cooperative with the company.

For most Americans, time is money and hence a valuable asset. Further, Americans like to prioritize issues according to the immediacy of their impact. However, South Koreans emphasizes on group consensus and 
deference to senior managers, an American businessman would have to expect a longer wait time in order for them to get approval and direction from the CEO.

\section{Bases of Trust}

Trust building is important. If two partners set up trust, paper contracts are not that important for South Koreans. It takes time to build up trust with foreigners. They prefer to work with someone they know or being recommended through an agent. They have more group sense than dealing with an individual they do not know of.

\section{Risk-Taking Propensity}

A South Korean proverb, "So-tahmdae-shil: Greed over small things loses big things”. However, there is a high risk associated with this approach when it is used by a counterpart for his/her own benefit. If the counterpart is only interested in short-term profits and does not want to have a long-term relationship, this approach will only result in a loss on the Korean side. This very traditional, risky, ethical, and Confucian approach seems to explain Koreans' approach to risk taking.

South Koreans think, "if you are egocentric, you might be successful for a short period of time, but you will lose eventually." It is very important for Koreans to keep a harmonious relationship considering the feelings of others and making group consensus before making the deals.

\section{Internal Decision-Making Systems}

One manager who was experienced in negotiating with managers from all three countries commented, "I was surprised to find how quickly things can be done in Korea”. Several plausible reasons can be provided to explain this difference. First, the smaller size of the South Korean negotiating team reaches inner consensus. Second, members of the negotiating team appear to have broader powers of decision-making. Third, decision-making in South Korean companies is typically highly centralized in the hands of top management. However, since relationships are very important in the South Korean context and they use time as a stalling tactic to gain more concessions from the Americans, negotiations still may not progress as rapidly as they do at home. South Koreans may also change their decisions quickly, their decisions are often influenced by the mood or mental state at the time of negotiation.

\section{Form of Satisfactory Agreement}

The South Korean view of the final contract is very similar to that of the Chinese in many respects. They sign contracts with foreign business people to get the relationship started officially. Therefore everything is subject to change and negotiation even after signing the contract. The South Koreans do not regard the provisions of a contract as sacrosanct. They regard the personal relationship and the desire for mutual benefits as the foundation of any business arrangement. In other words, a contract is essentially nothing more than a symbol of this relationship.

\section{Conclusion}

It is important to attain "Win-Win" outcomes in dealing with South Korean negotiators. It is more important to develop and nurture the relationships between the parties rather than trying to reach any kind of initial agreement. Americans should keep in mind that the South Korean negotiators may engage in a different 
logical process. In addition, American negotiator should not feel the urge to conclude without fully understanding what they are making commitments to. South Koreans' decision making may take a longer period of time than expected. Thus, Americans need to be more patient and to allow adequate time for their partners to ponder over issues. When resolving conflicts between the parties, legal remedy is not well received by South Koreans. In general, compromise is preferred. The attitude toward legal contracts is very different between Westerners and Koreans. In South Korea, on the other hand, a contract is viewed primarily as a symbol of the relationship. Accordingly, it will work to the Americans' advantage to show flexibility and leave room for renegotiation in the future.

South Korean President Park Chung Hee formulated a 5-year plan to boost the South Korea economy with several goals. The ambitious plan had simply looked for better policies in modernizing and preparing for long-term economic success. For the United States companies who want to work with Koreans, these interests and goals are regarded in order to better understand each other's perspectives.

\section{References}

Burnaby, B., \& Sun, Y. L. (June 1989). Chinese teachers' views of Western language teaching: Context informs paradigms. TESOL Quarterly, 23(2).

Carter, D. (1983). Some propositions about ESP. The ESP Journal, (2), 131-137.

Choe, S. T. (1993). Library and Information Resources Network, Inc. Retrieved July 30, 2013 from http://search.proquest.com.ezp-02.lirn.net/docview/213104138?accountid=158574

Celce-Murcia, M. (2003). Teaching English as a second or foreign language. Boston, MA: Heinle \& Heinle.

Crystal, D. (2003). The Cambridge encyclopedia of the English language (2nd ed.). Cambridge: Cambridge University Press.

Dudley-Evans, T. (2001). English for specific purposes. In R. Carlter and D. Nunan (Eds.), Teaching English to speakers of other languages: A Cambridge guide (pp. 131-136). Cambridge: Cambridge University Press. Retrieved from http://dx.doi.org/10.1017/CBO9780511667206.020

Dudley-Evans, T., \& St John, M. (1998). Developments in English for specific purposes. Cambridge: Cambridge University Press.

Fisher, R., Ury, W., \& Patton, B. (2011). Getting to yes: Negotiating agreement without giving in. New York: Penguin.

Gatehouse, K. (2001). Key issues in English for specific purposes (ESP) curriculum development. The Internet TESL Journal, VII(10). Retrieved March 9, 2008 from http://iteslj.org/Articles/Gatehouse-ESP.html

Guardado, M (March 2002). Loss and maintenance of first language skills: Case studies of Hispanic Families in Vancouver. Modern Language Review, 58(3).

Hulsen M., de Bot K., \& Weltens, B. (2002). Between two worlds. Social networks, language shift and language processing in three generations of Dutch migrants in New Zealand. International Journal of the Sociology of Language, 153, 27-52.

Hutchinson, T., \& Waters, A. (1987). English for specific purposes: A learning-centered approach. Cambridge: Cambridge University Press.

Kang, S. (October-December 1999). Learning styles. Forum, 37(4), 6.

Kennedy, P (2002). Learning cultures and learning styles: Myth-understandings about adult (Hong Kong) Chinese learners. International Journal of Life Long Education, 21(5).

Lee, C. Y. (October 2012). Library and Information Resources Network, Inc. Retrieved July 30, 2013 from http://search.proquest.com.ezp-02.lirn.net/docview/1326437480?accountid=158574

Lee, Y. I. (June 2008). Library and Information Resources Network, Inc. Retrieved July 30, 2013 from http://search.proquest.com.ezp-02.lirn.net/docview/208144278?accountid=158574

Lewicki, R. J., Barry, B., \& Saunders, D. M. (2007). Negotiation: Readings, exercises, and cases. Boston: McGraw-Hill/Irwin.

Livermore, D. A. (2011). The cultural intelligence difference: Master the one skill you can't do without in today's global economy. New York: American Management Association.

Noels, K. A., Pelletier, L. G., Clément, R., \& Vallerand, R. J. (2000). Why are you learning a second language? Motivational orientations and self-determination theory. Language Learning, (50), 57-85

Oster, J. (March 1989). Seeing with different eyes: Another view of literature in the ESL class. TESOL Quarterly, 23(1).

Reid, J. M. (1998). Understanding learning styles in the second language classroom. New York: Prentice Hall Regents. 
Robinson, P. (1980). ESP (English for specific purposes). New York: Pergamon.

Robinson, P. (1991). ESP today: A practitioner's guide. New York: Prentice Hall.

Samovar, L. A., \& Porter, R. E. (2003). Intercultural communication (10th ed.). Belmont, CA: Wadsworth: Thomson.

Searfoss, L. W., Smith, C. C., \& Bean, T. W. (December 1981). An integrated language strategy for second language learners. TESOL Quarterly, 15(4).

Taylor, B. P. (1975). Adult language learning strategies and their pedagogical implications. TESOL Quarterly, 9(4).

Wharton, (2000). Language learning strategy use of bilingual foreign language learners in Singapore. Language Learning, 50(2), 203-243. 